\title{
Raman-based geobarometry of ultrahigh-pressure metamorphic rocks: applications, problems, and perspectives
}

\author{
Andrey V. Korsakov • Vladimir P. Zhukov • \\ Peter Vandenabeele
}

Received: 27 November 2009/Revised: 27 April 2010 / Accepted: 5 May 2010 /Published online: 26 June 2010

(C) Springer-Verlag 2010

\begin{abstract}
Raman-based geobarometry has recently become increasingly popular because it is an elegant way to obtain information on peak metamorphic conditions or the entire pressure-temperature-time (P-T-t) path of metamorphic rocks, especially those formed under ultrahigh-pressure (UHP) conditions. However, several problems need to be solved to get reliable estimates of metamorphic conditions. In this paper we present some examples of difficulties which can arise during the Raman spectroscopy study of solid inclusions from ultrahigh-pressure metamorphic rocks.
\end{abstract}

Keywords Raman spectroscopy - Thermoelastic model · Coesite $\cdot$ Quartz $\cdot$ Aragonite $\cdot$ Calcite

\section{Introduction}

Recovery of peak metamorphic conditions for ultrahighpressure metamorphic (UHPM) rocks is a big challenge,

\footnotetext{
A. V. Korsakov $(\square)$

Institute of Geology and Mineralogy of Siberian Branch

of the Russian Academy of Sciences,

Koptyug Pr. 3,

Novosibirsk 630090, Russia

e-mail: korsakov@igm.nsc.ru

e-mail: korsakov@uiggm.nsc.ru

\section{P. Zhukov}

Institute of Computational Technologies of Siberian Branch of the Russian Academy of Sciences,

Acad. Lavrentjev avenue 6,

630090 Novosibirsk, Russia

P. Vandenabeele

Department of Archaeology, Ghent University,

Sint-Petersnieuwstraat 35,

9000 Ghent, Belgium
}

because frequently these rocks undergo nearly isothermal decompression hiding any sign of the UHP stage. Coesite and diamond are the best mineral indicators that the mineral assemblages in crustal-derived metamorphic rocks were formed at depths of more than $90 \mathrm{~km}$ and more than $120 \mathrm{~km}$, respectively [1-3]. Raman spectroscopy was originally used to prove the presence of relics via UHP mineral indicators (e.g., diamond or coesite) [1-4]. Only recently has the pressure dependence of the Raman bands started to be used as a new type of geobarometer [5-7]. For instance very high residual pressure was confirmed by Raman spectroscopy for different solid phase inclusions in refractory minerals (e.g., diamond, garnet, kyanite, zircons) formed in the coesite or diamond stability field (see [5-11] and references therein).

It is noteworthy that coesite inclusions in refractory minerals (e.g., garnet, kyanite, zircon, clinopyroxene) from different UHPM complexes exhibit different degrees of retrogression to quartz $[1,2,8,11]$. Raman spectroscopic study of these two $\mathrm{SiO}_{2}$ polymorphs clearly indicates different residual pressure within the single inclusions of 2.0-2.3 GPa for coesite and $0.8-1.5 \mathrm{GPa}$ for quartz, respectively $[6,8,10,11]$. This discrepancy is inconsistent with local equilibrium postulates, which are milestones of metamorphic petrology. Furthermore despite the presence of a strong optical halo in the host garnet around such bimineralic coesite-quartz inclusions (Figs. 1,2 and 3) no measurable overpressure was documented by Raman spectroscopy in the host garnet adjacent to inclusions [8].

Complex aragonite-calcite inclusions in garnet from diamond-bearing calcite marbles without measurable upshift of Raman bands for both polymorphs of $\mathrm{CaCO}_{3}$ clearly indicate very low values of overpressure for the aragonite and calcite [12]. Lack of overpressure for these inclusions is inconsistent with their UHPM origin. However, 
Fig. 1 Microphotographs of bimineralic coesite (Coe)-quartz $(Q t z)$ inclusion in garnet $(G r t)$ from diamond-bearing clinozoisite gneisses (sample B94-331a) from the Barchi-Kol area (Kokchetav massif, Northern Kazakhstan): an overview (a, b) and details (c, d). The inclusion is surrounded by an optical halo. Note that the quartz shell is optically invisible and was detected by Raman spectroscopy; for detail see [8]
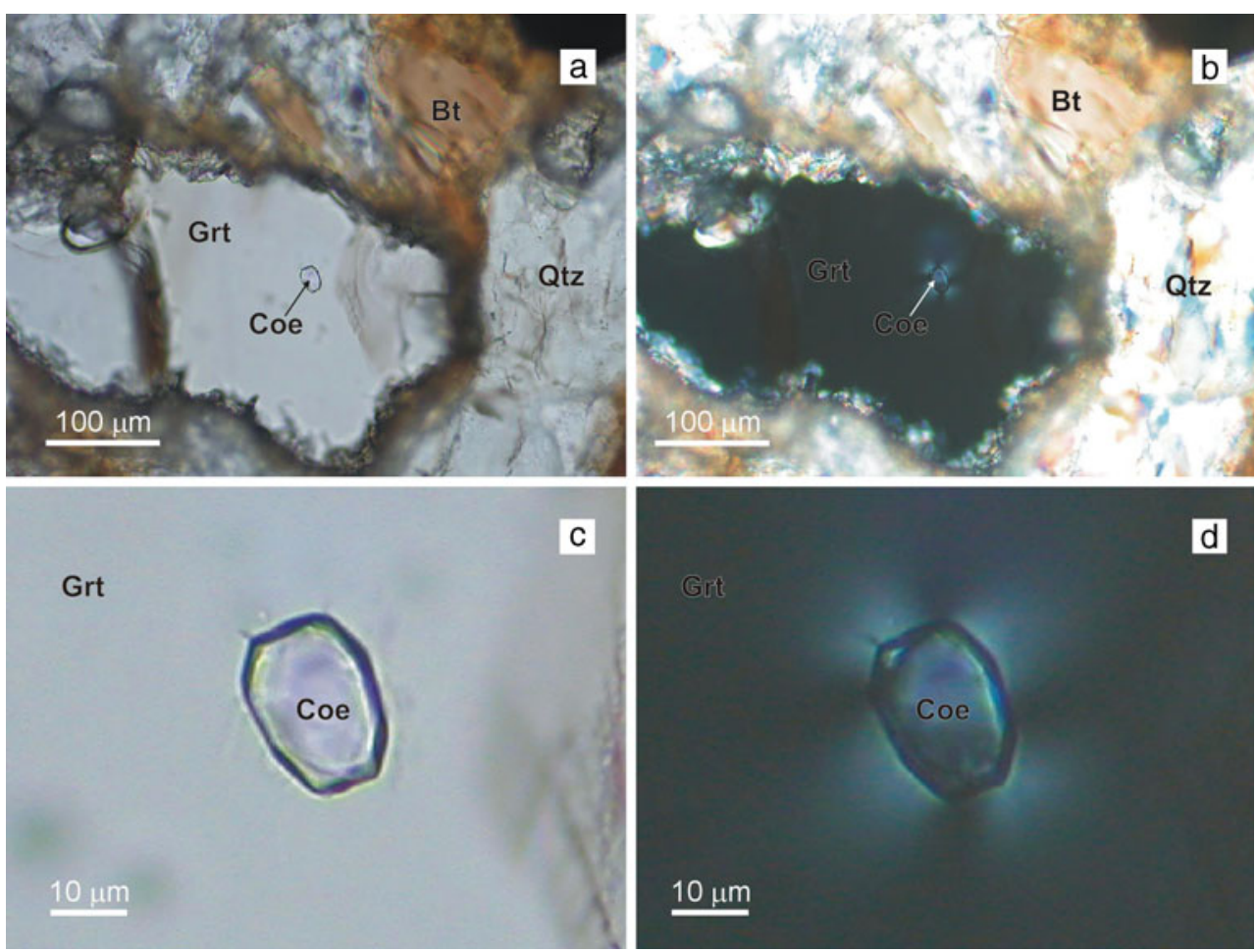

there are several independent pieces of evidence (e.g., diamond or K-bearing clinopyroxene inclusions) for the UHPM origin of the host garnet; therefore all inclusions must also have formed under UHPM conditions. The problems of Raman-based geobarometry can be summarized as follows:

- Differences of pressure values exist for solid phases within the single multiphase inclusions

- Significant differences in pressure exist between inclusion and host mineral

- There is an influence of the symmetry of the solid inclusion on the strain pattern inside the inclusion

In this paper we would like to discuss whether these problems indeed belong to Raman spectroscopy per se or are simply related to inadequate models which are generally used in petrology.

\section{Experimental techniques}

Raman spectra were obtained by using a Kaiser System Hololab 5000R modular Raman microspectrometer ( $f / 1.8)$ (KOSI, Ecully, France). The microscope was fitted with a $\times 100$ objective (PL Fluotar L, N.A. 0.75, W.D. $4.7 \mathrm{~mm}$, Leica). Samples were excited by using $45-50 \mathrm{~mW}$ of $785-$ $\mathrm{nm}$ laser light from a diode laser (Toptica Photonics AG, Martinsried/ Munich, Germany). The scattered light was guided to the spectrograph by means of a confocal, $15-\mu \mathrm{m}$
Fig. 2 Raman maps of band intensity of main bands of coesite (a) and quartz (b); for details see [8]
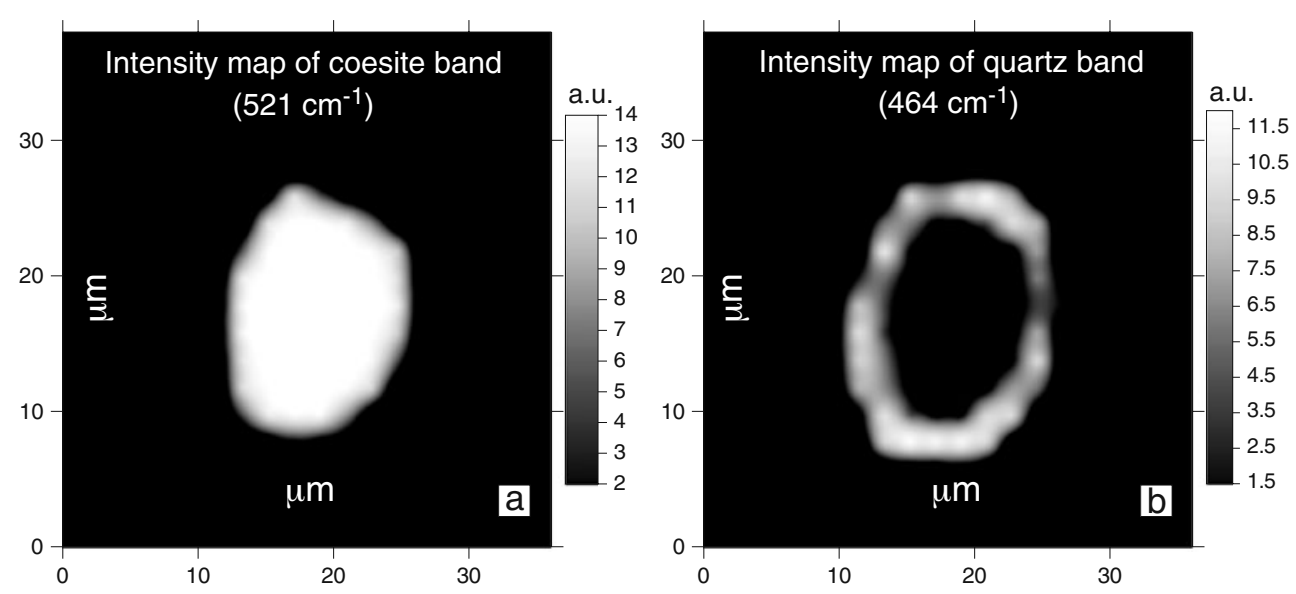


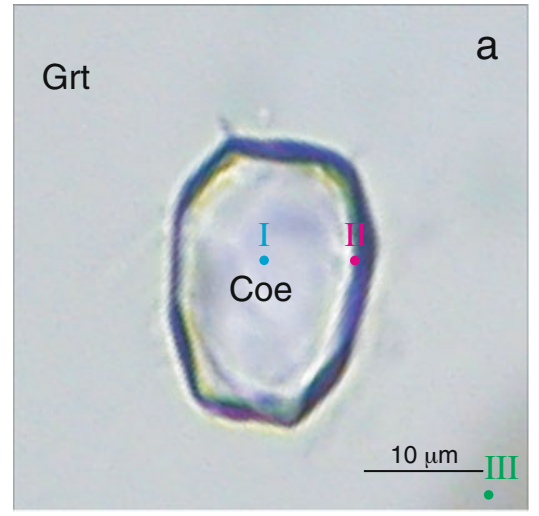

Fig. 3 Microphotographs of bimineralic coesite (Coe)-quartz inclusion in garnet (Grt) (a) and representative Raman spectra of $I$ coesite (blue), II quartz (red), and III garnet (green). Band positions of quartz and coesite, which were used to estimate the residual pressure, are

aperture collection fiber. A back-illuminated deep depletion Peltier-cooled CCD detector (Andor, Belfast, Northern Ireland) operating at $-70{ }^{\circ} \mathrm{C}$ was used for the detection of the scattered light. The Raman signal was collected in the spectral interval of $100-3,100 \mathrm{~cm}^{-1}$ with a spectral resolution of $4 \mathrm{~cm}^{-1}$. The spectra were recorded with 15-s accumulation time. Further details of the calibration procedure can be found elsewhere [13]. Several $20 \times 20$ Raman mappings were performed with a spacing of $1.5-$ $2 \mu \mathrm{m}$ for coesite inclusions in garnet from garnetclinozoisite-biotite gneisses described in detail elsewhere $[14,15]$.

\section{Samples}

Three samples including aragonite, quartz, and coesite inclusions in garnet from the Kokchetav massif (Northern Kazakhstan) are presented in this study. An influence of the symmetry of the solid inclusion on the strain patterns inside the inclusions was of interest. All studied inclusions are located several microns below the surface. The unexposed inclusions were chosen to avoid the possible partial or complete relaxation of strain. However, as was shown recently $[8,16]$, the pressures do not relax completely even for inclusions partly exposed at the surface.

Aragonite inclusions in garnet

Aragonite inclusions were only recently identified in diamond-grade metamorphic rocks by using Raman spectroscopy $[16,17]$. Complex polycrystalline inclusion consisting of aragonite-calcite and monocrystalline aragonite inclusions from diamond-bearing marbles (sample GAK101) from the Kumdy-Kol microdiamond deposit

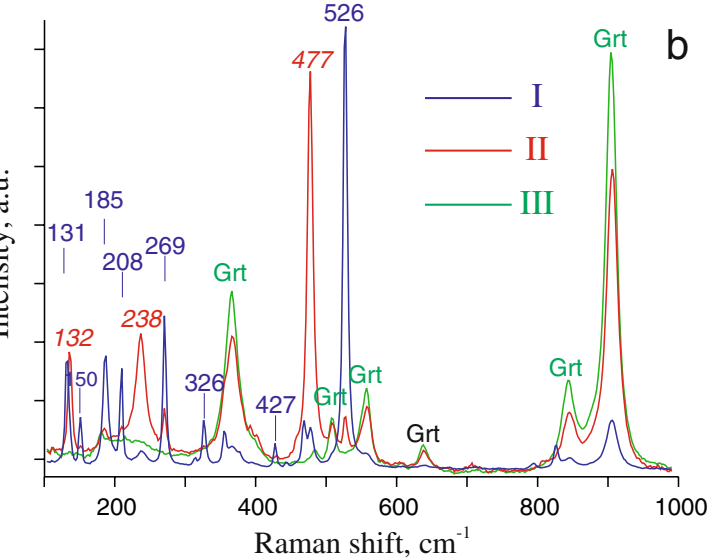

indicated by italic and normal font, respectively. Residual pressure for coesite and quartz were estimated based on pressure dependency of positions of Raman bands from [34]

(Kokchetav massif ) were selected for this study (Fig. 4). The complex polycrystalline aragonite-calcite inclusion was described in detail in [12]. Almost all polycrystalline aragonite-bearing inclusions display rounded shapes and a sharp carbonate-garnet interface. The lack of dense radial crack patterns around the aragonite-bearing inclusions is another typical feature of this type of inclusion. Some polycrystalline carbonate inclusions contain fine-grained dirty aggregates with high interference colors (see Fig. 5a, b [12] and Fig. 6). Calcite coexisting with aragonite, at least on an optical basis, behaves as a monocrystal, although the orientation of aragonite is often different from the orientation of calcite.

Monocrystalline inclusions of aragonite in garnet (sample GAK101) were identified for the first time for diamondgrade metamorphic rocks. These inclusions are characterized by rounded shapes similar to polycrystalline aragonitecalcite inclusions and are subhedral or rarely euhedral. No radial crack pattern was found to be associated with monocrystalline aragonite inclusions (Fig. 4c, d). Estimates of peak metamorphic conditions are as high as $T=950$ $1,050{ }^{\circ} \mathrm{C}$ and $P \sim 6.5 \mathrm{GPa}[18,19]$.

Quartz inclusions in garnet

The monocrystalline quartz inclusions are very common inclusions in metamorphic garnet. In our study we focus on monocrystalline quartz inclusions which also have birefringent halos of different intensity (Fig. 5). This type of quartz inclusions is very common in garnet-kyanitequartz-micaschists from the Barchi-Kol area [14, 15], as well as the Kulet area. The detail of geological settings and sample descriptions can be found elsewhere [10, 16, 20-23]. Here we will summarize only the most important features. The quartz inclusions are variable in size (up to $100 \mu \mathrm{m}$ in 
Fig. 4 Microphotographs of bimineralic calcite-aragonite inclusion (a, b) and monocrystalline aragonite $(A r)$ inclusion (c, d) in garnet (Grt) from diamond-bearing calcite $(\mathrm{Cal})$ marble (sample GAK101) from Kumdy-Kol microdiamond deposit (Kokchetav massif, Northern Kazakhstan)
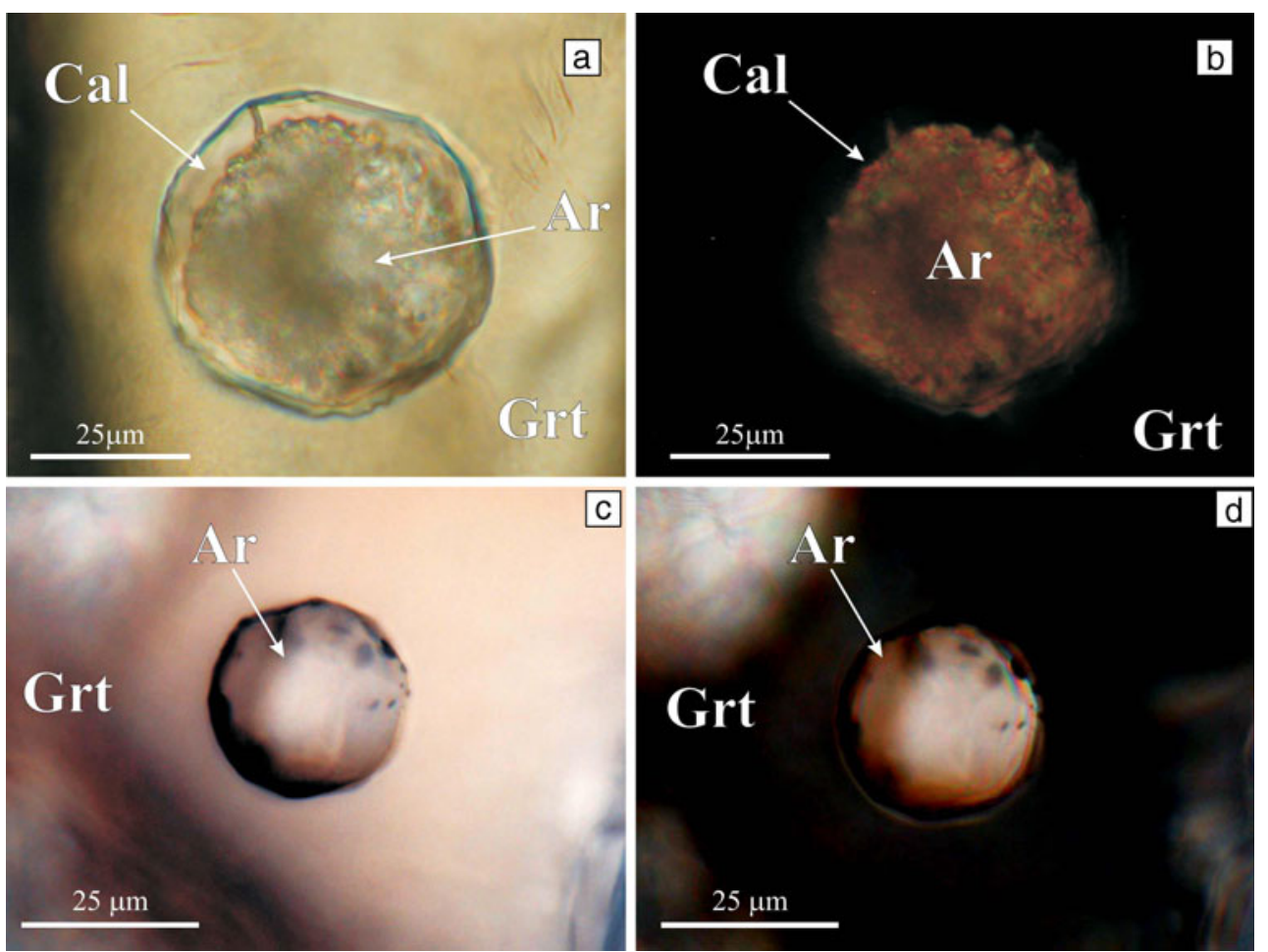

diameter) and are extremely abundant in the core of some garnet porphyroblasts (Fig. 5). These garnet porphyroblasts have typical prograde zoning pattern (e.g., $\mathrm{MnO}$ decreases from core to rim; see Fig. 7 [10]). All monocrystalline quartz inclusions are euhedral and are surrounded by birefringent halo, but no correlation was found between size and intensity of the halo and size of quartz inclusions. Some of the inclusions are also surrounded by tiny radial cracks (see [16], Fig. 4), a common feature of coesite inclusions [1, 2]. The peak metamorphic conditions for the sample are estimated to be as high as $600-650{ }^{\circ} \mathrm{C}$ and $1.6-2.4 \mathrm{GPa}$ [16].
Fig. 5 Microphotographs of monocrystalline quartz $(Q t z)$ inclusions in garnet $(\mathrm{Grt})$ from the garnet-kyanite-quartzmicaschist from the Barchi-Kol area, Kokchetav massif (sample B01-3) obtained by using a-c plane-polarized light and $\mathbf{b}-\mathbf{d}$ cross-polarized light. There is a radial crack pattern or an optical birefringent halo around the quartz inclusion indicating relatively high values of residual pressure inside the inclusion
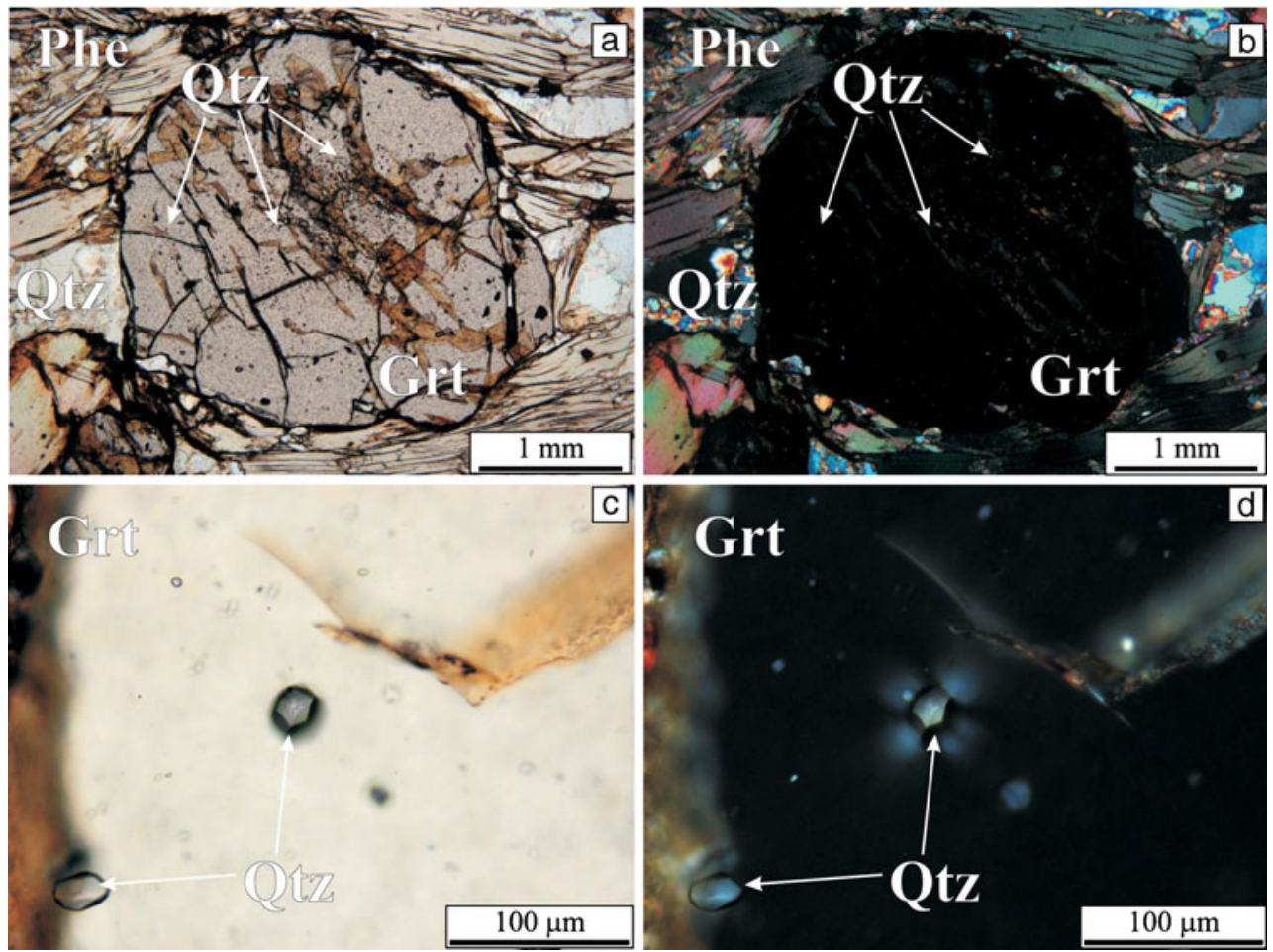


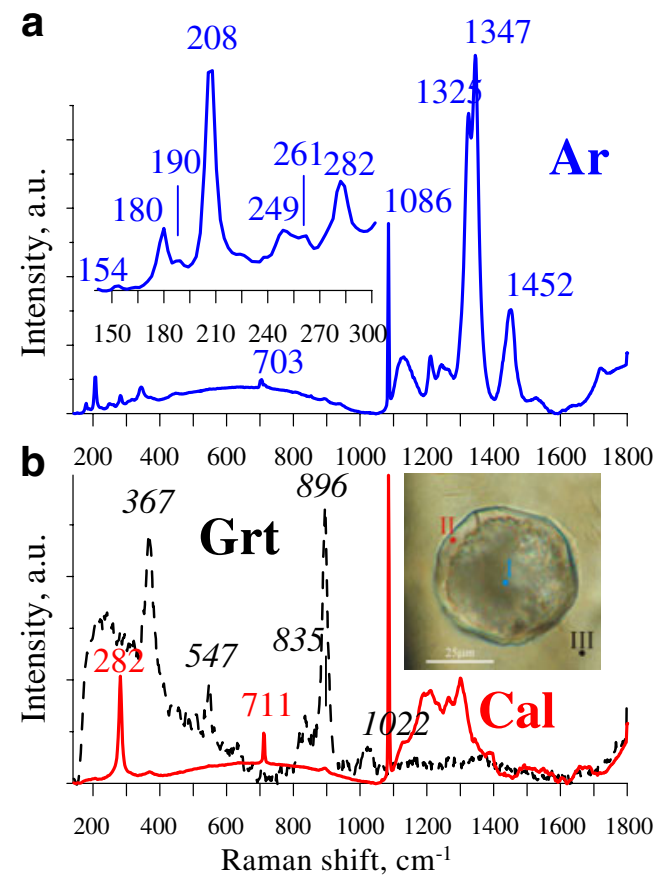

Fig. 6 Representative Raman spectra of a aragonite (blue spectrum) and $\mathbf{b}$ calcite (red spectrum) from polycrystalline carbonate inclusion and garnet host (black spectrum)

\section{Coesite inclusions in garnet}

For this study we selected unexposed coesite inclusions in garnet from the garnet-clinozoisite-biotite gneisses (B94331 a) $[14,15]$, because in this rock type coesite is very well preserved and there is no trace of quartz, which can be detected by optical microscopy (Fig. 1). The inclusion is euhedral and slightly elongated, about $17 \times 22 \mu \mathrm{m}$ in size. The very tiny cracks occur at apices of coesite inclusions (Fig. 1c). This inclusion, as well as many others from this sample, is surrounded by a strong optical birefringent halo (Fig. 1d).
The P-T parameters of peak metamorphic conditions for this rock are estimated to be as high as greater than $4 \mathrm{GPa}$ and $900-1,000{ }^{\circ} \mathrm{C}$ [14]. Retrograde stage was also relatively well defined at $650-750{ }^{\circ} \mathrm{C}$ and $1.0-1.2 \mathrm{GPa}$ $[14,24]$.

\section{Results of Raman microspectroscopic study}

Aragonite inclusions in garnet

Carbonates are distinguishable by their diagnostic Raman spectra ([25-32] and references therein). However, the pressure dependence of the vibrational frequencies is only well known in the case of particular carbonates [28]. Because of the small sample volumes and the possibility to analyze unexposed inclusions, nondestructive Raman mapping is a very promising tool for the identification and study of the spatial distribution of carbonates within inclusions.

The two polymorphs of $\mathrm{CaCO}_{3}$, calcite and aragonite, were distinguished in the samples studied by analyzing their diagnostic Raman spectra (Figs. 6, 7 and Table 1).

Calcite is characterized by a strong band at $1,086 \mathrm{~cm}^{-1}$, along with other weaker bands at 156,283 , and $713 \mathrm{~cm}^{-1}$ [33]. The main band of aragonite is also located at $1,086 \mathrm{~cm}^{-1}$ with subsidiary bands at $154,181,191,208$, 249, 261, 273, 283, and $704 \mathrm{~cm}^{-1}$ [33]. Only the bands marked in italics were documented in this study. The host garnet is characterized by a strong band at $896 \mathrm{~cm}^{-1}$, along with other weaker bands at $367,547,835$, and $1,022 \mathrm{~cm}^{-1}$ (Fig. 7). A slight downshift of roughly $1 \mathrm{~cm}^{-1}$ in the $283 \mathrm{~cm}^{-1}$ calcite band was observed. A weak band appears at $282 \mathrm{~cm}^{-1}$ in the aragonite spectrum. Most likely this band is caused by very fine-grained calcite-aragonite intergrowth, because the band at around $283 \mathrm{~cm}^{-1}$ in the Raman spectrum of aragonite is generally very weak [33].

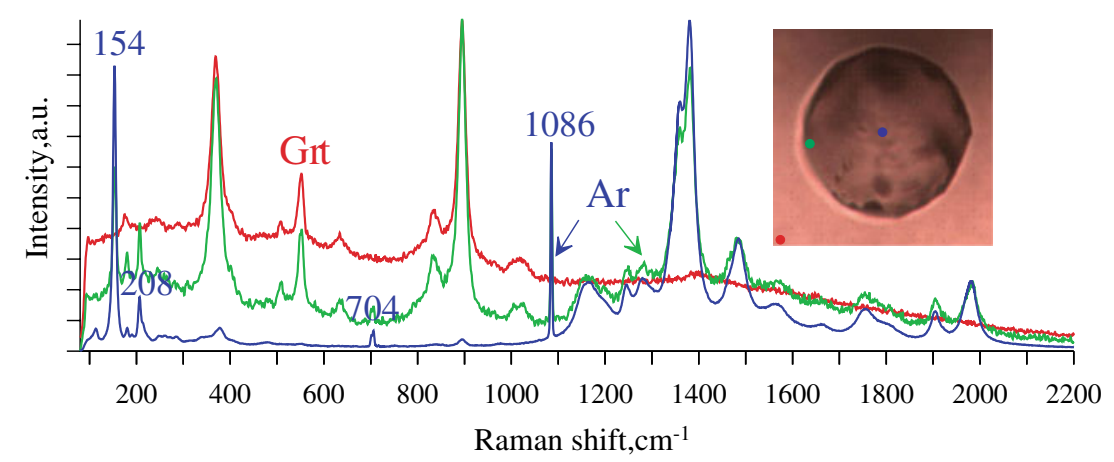

Fig. 7 Representative Raman spectra of a aragonite (blue and green spectra) from monocrystalline carbonate inclusion and garnet host (black spectrum) from monocrystalline aragonite inclusion. Points of location are marked on the photo (inset) by using the same colors as the corresponding spectra. No trace of optically undetectable calcite was found within the inclusion by Raman mapping, presented in Fig. 8 

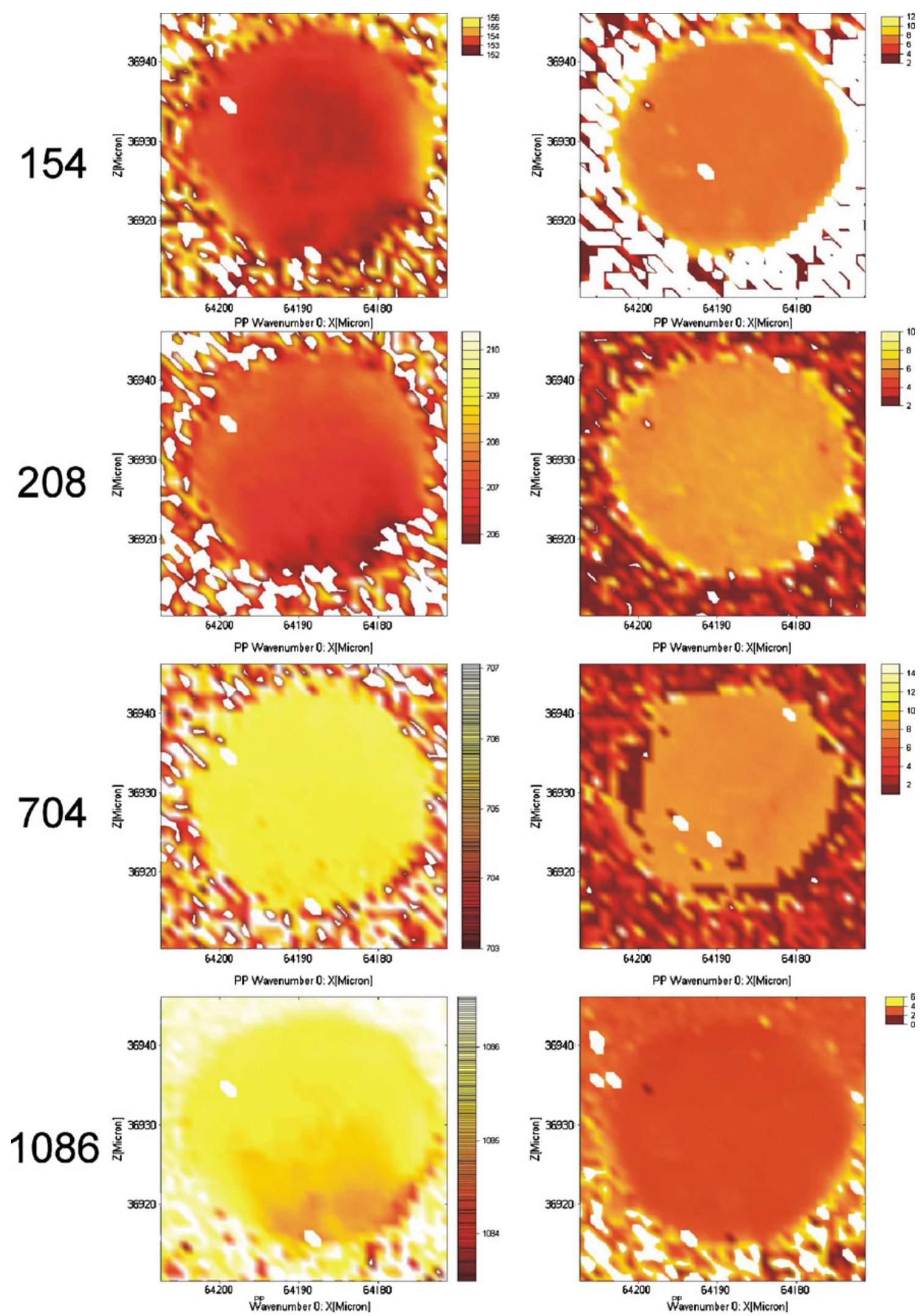

Fig. 8 Raman maps of main aragonite bands 154, 208, 711, and $1086 \mathrm{~cm}^{-1}$ position (left column) and FWHM (right column). There are no measurable upshifts or broadening of aragonite bands, indicating lack of overpressure inside aragonite the inclusion 
Table 1 Wavenumbers $\left(\mathrm{cm}^{-1}\right)$ of calcite and aragonite Raman bands in spectra of representative unexposed polycrystalline and monocrystalline inclusions

\begin{tabular}{|c|c|c|c|c|c|c|c|c|c|}
\hline \multicolumn{4}{|l|}{ Calcite } & \multicolumn{6}{|l|}{ Aragonite } \\
\hline & & & & \multirow[b]{2}{*}{$\nu^{*}\left(\mathrm{~cm}^{-1}\right)$} & \multirow[b]{2}{*}{$\mathrm{d} \nu / \mathrm{d} P\left(\mathrm{~cm}^{-1} / \mathrm{GPa}\right)$} & \multicolumn{2}{|c|}{ Polycrystalline } & \multicolumn{2}{|c|}{ Monocrystalline } \\
\hline$\nu^{*}\left(\mathrm{~cm}^{-1}\right)$ & $\mathrm{d} \nu / \mathrm{d} P\left(\mathrm{~cm}^{-1} / \mathrm{GPa}\right)$ & $\nu\left(\mathrm{cm}^{-1}\right)$ & $P_{\mathrm{i}}(\mathrm{GPa})$ & & & $\nu\left(\mathrm{cm}^{-1}\right)$ & $P_{\mathrm{i}}(\mathrm{GPa})$ & $\nu\left(\mathrm{cm}^{-1}\right)$ & $P_{\mathrm{i}}(\mathrm{GPa})$ \\
\hline & & & & 155 & $2.7 \pm 0.2$ & 154 & $10^{-4}$ & 154 & $10^{-4}$ \\
\hline \multirow[t]{3}{*}{156} & $2.47 \pm 0.3$ & 156 & $10^{-4}$ & & & & & & \\
\hline & & & & 180 & $3.4 \pm 0.6$ & 180 & $10^{-4}$ & 180 & $10^{-4}$ \\
\hline & & & & 209 & $3.3 \pm 0.5$ & 207 & $10^{-4}$ & 207 & $10^{-4}$ \\
\hline \multirow[t]{2}{*}{283} & $5.27 \pm 0.4$ & 282 & -0.19 & & & & & & \\
\hline & & & & 702 & $1.5 \pm 0.1$ & 702 & $10^{-4}$ & 702 & $10^{-4}$ \\
\hline 713 & $2.22 \pm 0.2$ & 713 & $10^{-4}$ & & & & & & \\
\hline 1,086 & $5.87 \pm 0.4$ & 1086 & $10^{-4}$ & 1,084 & $2.3 \pm 0.2$ & 1,086 & $10^{-4}$ & 1,086 & $10^{-4}$ \\
\hline
\end{tabular}

Pressure shifts of the Raman modes of calcite and aragonite were obtained from [28]. Differences between theoretical and measured values of wavenumbers are likely due to different analytical conditions

$\nu^{*}$ theoretical, $\nu$ measured in this study, $P_{\mathrm{i}}$ residual pressure in inclusion

Several additional very intense and rather narrow bands appear around 1,325, 1,347, and $1,452 \mathrm{~cm}^{-1}$ in the aragonite spectrum (Fig. 7a). When excited with a different laser source $\left(\mathrm{Ar}^{+}, 514.5 \mathrm{~nm}\right)$ the aragonite exhibited no band at these positions. Thus, these bands are considered to be luminescent bands. Calcite also has several luminescent bands, but these are generally broader and less intense (Fig. 7b).

Raman mapping of a polycrystalline carbonate inclusion revealed mainly calcite and an area with bands, typically assigned to aragonite (Fig. 9). The band position of aragonite and calcite corresponds to literature spectra obtained at ambient conditions (Fig. 7 and Table 1). The measured Raman band positions might also be slightly affected by the analytical conditions and exhibit slight differences compared to the literature ones (different calibration standards, slit width, gratings, etc.). It can thus be misleading to check whether minor Raman band shifts indicate residual overpressure inside the inclusion. When a subsurface inclusion is exposed at the surface through polishing, its residual pressure disappears. Hence, one inclusion was exposed at the thin section surface and reanalyzed to detect residual pressures. The band positions of calcite and aragonite are equal to the positions of the intact inclusion. This observation implies that no measurable shifts of the main Raman band of calcite and aragonite in the polycrystalline inclusion were overlooked.

Quartz inclusions in garnet

Coesite and $\alpha$-quartz are distinguishable by their diagnostic Raman spectra. Coesite is characterized by a strong band at $521 \mathrm{~cm}^{-1}$, along with other weaker bands at $116,151,176$,
204, 269, 326, 355, 427, 466, 661, 795, 815, 1,036, 1,065, 1,144 , and $1,164 \mathrm{~cm}^{-1}$ at room temperature and atmospheric pressure $[4,34,35]$. The main band of $\alpha$-quartz is located at $464 \mathrm{~cm}^{-1}$ with subsidiary bands at $128,206,265,355,394$, $401,450,511,696,796,808,1,069,1,085,1,162$, and $1,230 \mathrm{~cm}^{-1}$ [34]. However, only bands marked in italic fonts were documented in this study. Host garnet is characterized by a strong band at $905 \mathrm{~cm}^{-1}$, along with other weaker bands at $180,231,366,485,508,557,638,845$, and $1,036 \mathrm{~cm}^{-1}$.

There is a significant shift of main quartz Raman bands for all quartz inclusions in garnet from sample B01-3 (Table 2). Representative Raman spectra are shown in Fig. 10. The highest shift of the main quartz band (up to $471 \mathrm{~cm}^{-1}$ ) was measured for an unexposed quartz inclusion. For inclusions partly exposed at the surface the shift is lower (about $467-468 \mathrm{~cm}^{-1}$ ), but these values are still higher than those for ambient pressure.

\section{Coesite inclusions in garnet}

Raman bands of "monomineralic" coesite inside unfractured garnet show various degrees of shift, indicating different values of overpressure. Some coesite inclusions, however, coexist within the same growth zone of host garnet at a distance less than $10 \mu \mathrm{m}$. Most likely these coesite inclusions formed under the same P-T conditions and consequently the differences in overpressure could not be explained by the simple elastic model proposed by Zhang [36]. Ye et al. [11] proposed that different values of overpressure related to differences in the extent of coesiteto-quartz transformation.

Raman mapping of the coesite inclusions in garnet reveals the following important features. Pressure inside 
Fig. 9 Raman maps of the polycrystalline carbonate inclusion presented in Fig. 4a, b
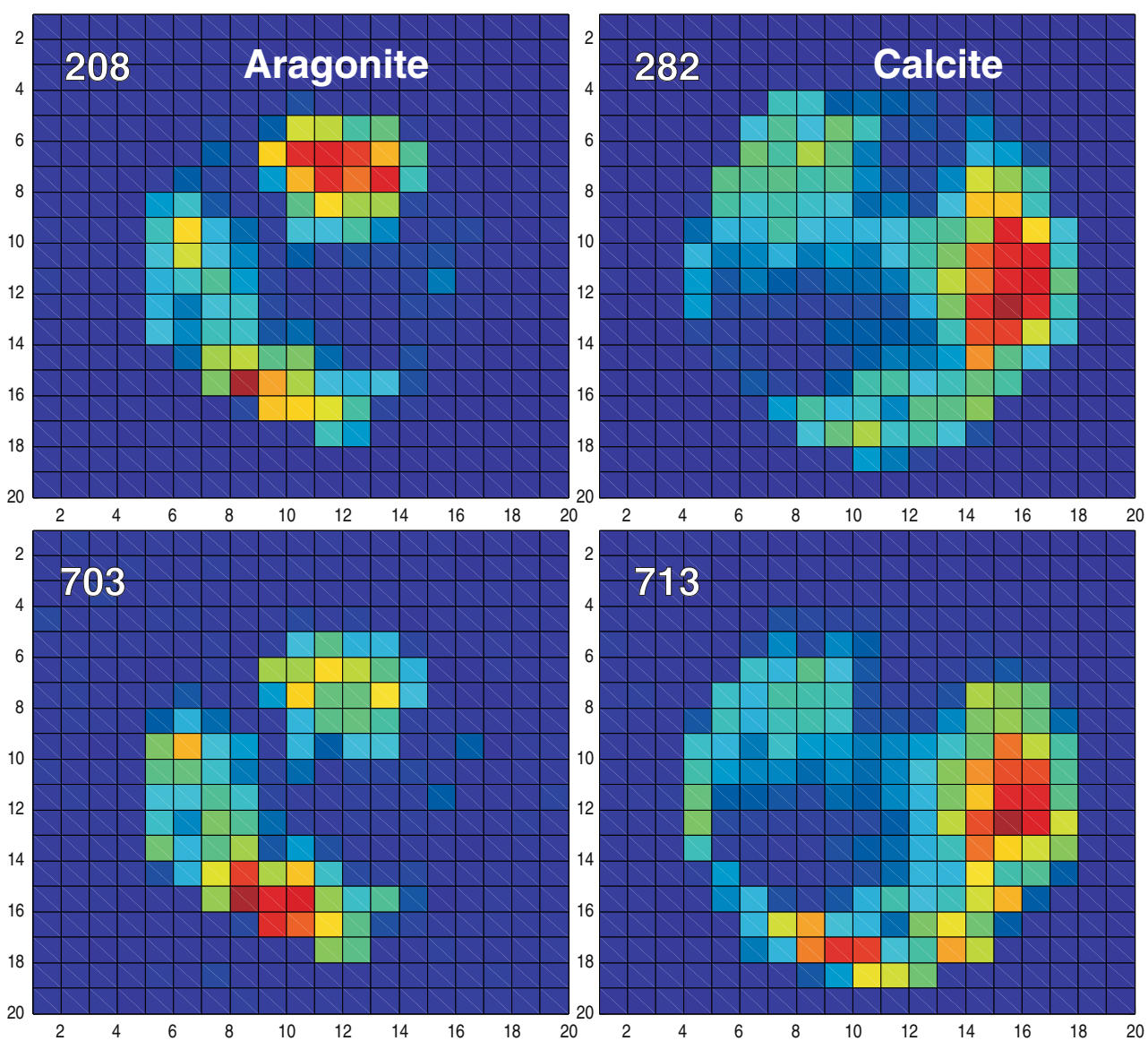

coesite inclusions (2.0-2.2 GPa) is uniform and isotropic [8]. Optically undetectable quartz shell occurs around the coesite core (Fig. 2b). Pressure estimates for quartz shell $(<1.6 \mathrm{GPa})$ based on pressure dependence of the main quartz Raman bands [34, 37] significantly differ from pressure values for coesite (2.0-2.2 GPa) (Table 2).

More pronounced pressure differences of $2.3 \mathrm{GPa}$ for coesite and 1.0 GPa for quartz were documented for

Table 2 Wavenumbers $\left(\mathrm{cm}^{-1}\right)$ of $\alpha$-quartz and coesite Raman bands in spectra of a representative unexposed inclusion

\begin{tabular}{|c|c|c|c|c|c|c|c|c|c|}
\hline \multicolumn{6}{|l|}{ Quartz } & \multicolumn{4}{|l|}{ Coesite } \\
\hline \multirow[t]{2}{*}{$\nu^{*}\left(\mathrm{~cm}^{-1}\right)$} & \multirow[t]{2}{*}{$\mathrm{d} \nu / \mathrm{d} P\left(\mathrm{~cm}^{-1} / \mathrm{GPa}\right)$} & \multicolumn{2}{|l|}{ B01-3 } & \multicolumn{2}{|l|}{ B94-331a } & \multirow[t]{2}{*}{$v^{*}\left(\mathrm{~cm}^{-1}\right)$} & \multirow[t]{2}{*}{$\mathrm{d} \nu / \mathrm{d} P\left(\mathrm{~cm}^{-1} / \mathrm{GPa}\right)$} & \multicolumn{2}{|l|}{ B94-331a } \\
\hline & & $v\left(\mathrm{~cm}^{-1}\right)$ & $P_{\mathrm{i}}$ & $v\left(\mathrm{~cm}^{-1}\right)$ & $P_{\mathrm{i}}$ & & & $v\left(\mathrm{~cm}^{-1}\right)$ & $P_{\mathrm{i}}$ \\
\hline 128 & $5.5 \pm 0.2$ & - & - & 132 & 0.73 & 116 & $7.4 \pm 0.4$ & 131.04 & 2.03 \\
\hline 206 & $19.9 \pm 0.7$ & 220 & 0.70 & 238 & 1.6 & 151 & $0.8 \pm 0.1$ & 150.29 & -0.85 \\
\hline 265 & $3.5 \pm 0.1$ & 267 & 0.57 & - & - & 176 & $5.6 \pm 0.2$ & 185.86 & 0.89 \\
\hline 355 & $-1.2 \pm 0.7$ & 353 & 1.67 & - & - & 204 & $2.3 \pm 0.3$ & 208.84 & 1.76 \\
\hline 394 & $-0.09 \pm 0.03$ & 393 & 11.11 & - & - & 269 & $1.1 \pm 0.2$ & 270.51 & 1.37 \\
\hline 401 & $-0.09 \pm 0.03$ & - & - & - & - & 326 & $1 \pm 0.1$ & 326.24 & 0.24 \\
\hline 450 & $4.6 \pm 0.1$ & 454 & 0.87 & - & - & 355 & $0.44 \pm 0.03$ & 355.42 & 0.95 \\
\hline 464 & $8.0 \pm 0.2$ & 469 & 0.63 & 477 & 1.63 & 427 & $0.45 \pm 0.04$ & 427.22 & 0.49 \\
\hline 696 & $7.0 \pm 0.6$ & 700 & 0.57 & - & - & 466 & $0.66 \pm 0.06$ & 468.32 & 3.52 \\
\hline 808 & $5.9 \pm 0.7$ & - & - & - & - & 521 & $2.9 \pm 0.1$ & 526.2 & 1.93 \\
\hline 1162 & $-3.1 \pm 0.3$ & 1,157 & 1.61 & - & - & & & & \\
\hline
\end{tabular}

Pressure shifts of the Raman modes of $\alpha$-quartz and coesite were obtained from [34]

$\nu^{*}$ theoretical, $\nu$ measured in this study, $P_{\mathrm{i}}$ residual pressure in inclusion 


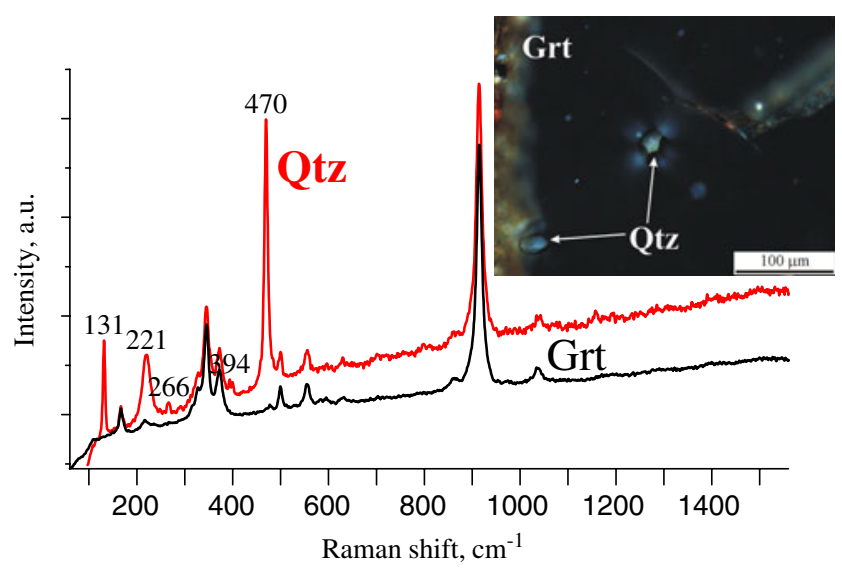

Fig. 10 Representative Raman spectra of monocrystalline euhedral quartz inclusions in garnet porphyroblast from sample B03-1. There is a radial crack pattern or an optical birefringent halo around the quartz inclusion indicating relatively high values of residual pressure inside the inclusion

different metamorphic complexes $[6,10,11]$. These differences may indicate that coesite and quartz are not in mechanical equilibrium. This fact is difficult to explain by using the simple elastic model of Zhang [36]. A multi-shell model was recently proposed by us [38]. The results of the modeling are presented below.

\section{Results of numerical thermoelastic modeling of multi-shell systems}

In numerical modeling we assume that a system consisting of spherical layers is formed at the pressure $P_{0}$ and temperature $T_{0}$. The first substance occupies the sphere of the radius $r_{1}$, the second one occupies the spherical layer $r_{1}<r<r_{2}$, and so on. The shear deformations initially were absent. Let the system change to an environment with the pressure $P$ and temperature $T$. We assume that during this change the system behaves as an elastic body. The possibility of phase transformation and changes of elasticity moduli with temperature are taken into account. The model allows one to calculate the thermodynamic possibility of phase transition. Note that the energy of shear deformation can strongly affect the phase equilibrium diagram. The model (Appendix) is described in detail elsewhere $[16,38]$. The thermodynamic data involved into the model are taken from [39].

Firstly we investigate the system initially consisting of $20-\mu \mathrm{m}$ coesite in a $1-\mathrm{mm}$ pyrope host, formed at the temperature $T_{0}=1,300 \mathrm{~K}$ and pressure $P_{0}=6 \mathrm{GPa}$ (Fig. 11a). At the final stage (ambient conditions $T=298 \mathrm{~K}, P=$ $0.0001 \mathrm{GPa}$ ) the system consists of coesite- $\alpha$-quartz-pyrope (Fig. 11b); for $r_{1}<r<20 \mu \mathrm{m}$ the coesite transforms to $\alpha$ quartz. Calculations show that the residual pressure within the coesite core is $\approx 2 \mathrm{GPa}$ for $r_{1}<10 \mu \mathrm{m}$ (thick quartz
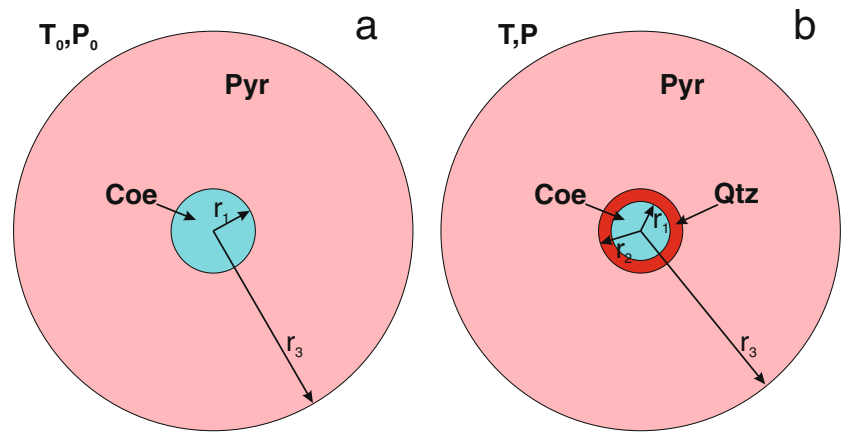

Fig. 11 Schematic drawings of multi-shell inclusions at initial (a) and final (b) stages. Pyr (pink) pyrope; Coe (blue) coesite; Qtz (red) quartz; $r_{1}, r_{2}$, and $r_{3}$ radii of coesite, quartz, and pyrope, respectively

envelope) and tends to $\approx 1.5 \mathrm{GPa}$ for $r_{1} \rightarrow 20 \mu \mathrm{m}$ (thin quartz envelope). This is in good agreement with pressure estimates, obtained by Raman upshift of the main coesite band, which give a value $\approx 2 \mathrm{GPa}[6,8,10,11]$.

But the model predicts higher $(\approx 3.5 \mathrm{GPa})$ pressure in the quartz shell in contrast to Raman measurements. According to our Raman spectroscopic study of coesite and quartz inclusions $[8,16]$ and published results $[6,10,11]$ lower pressure values, $\approx 1.5 \mathrm{GPa}$, were obtained for quartz shell, surrounding relics of coesite, based on hydrostatic calibration [34]. The variations of initial pressure and temperature have almost no effect on final stress distributions. There is a large pressure in the quartz shell because of high expansion during coesite-to-quartz transformation. The typical stress distributions are presented in Fig. 12. The values $\sigma_{\mathrm{t}}$ and $\sigma_{\mathrm{r}}$ correspond to tangential and radial components of the stress

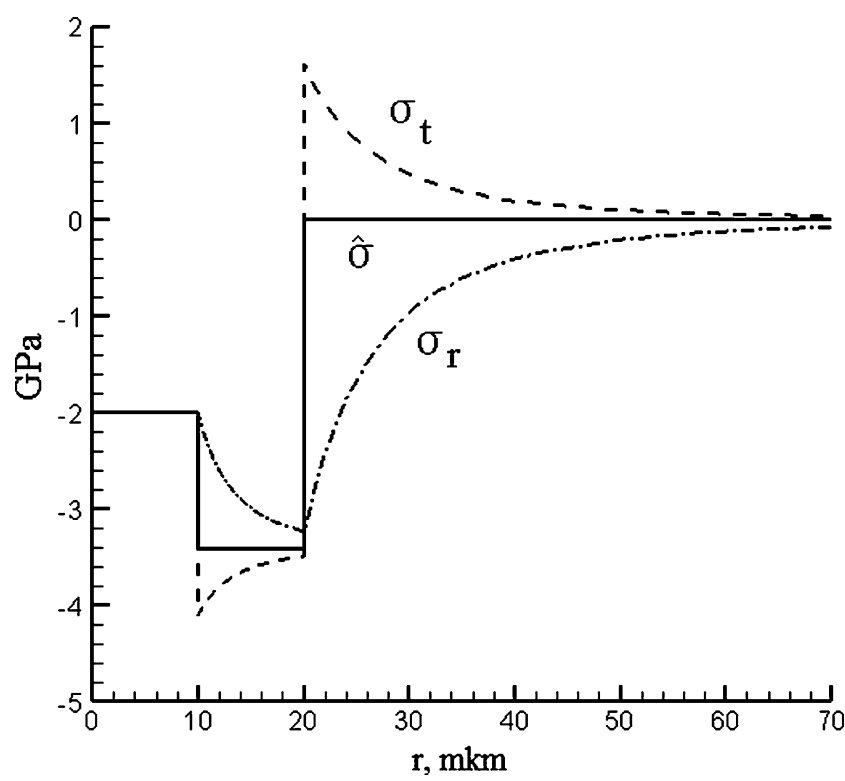

Fig. 12 Calculated radial $\left(\sigma_{\mathrm{r}}\right)$, tangential $\left(\sigma_{\mathrm{t}}\right)$, and $\widehat{\sigma}=\left(\sigma_{r}+2 \sigma_{t}\right) / 3=$ $-P$ stress distribution in coesite- $\alpha$-quartz-pyrope system for initial conditions: $T_{0}=1,300 \mathrm{~K}, P_{0}=6 \mathrm{GPa}, R_{\mathrm{Coe}, 0}=0.02 \mathrm{~mm}, R_{\mathrm{Pyr}}=1 \mathrm{~mm}$; and final conditions: $T=298 \mathrm{~K}, P=10^{-4} \mathrm{GPa}, R_{\mathrm{Coe}}=0.01 \mathrm{~mm}, R_{\mathrm{Qtz}}=$ $0.02 \mathrm{~mm}$, and $R_{\mathrm{Pyr}}=1 \mathrm{~mm}$. The elastic properties are taken from [39] 
tensor, respectively; $\widehat{\sigma}=\left(\sigma_{r}+2 \sigma_{t}\right) / 3$ corresponds to the negative value of the pressure measured in the experiments. Taking into account the possibility of pyrope cracking, by putting the pyrope shear modulus equal to 0 , we did not succeed in getting estimates comparable with results obtained by Raman mapping of coesite inclusions [8].

We also investigated the thermodynamic possibility of the transformation of coesite to quartz in the multi-shell systems. The calculations show that for high initial temperature and pressures $\left(P_{0} \sim 3 \div 6 \mathrm{GPa}, T_{0} \sim 1,300 \mathrm{~K}\right)$ the transition is thermodynamically forbidden. For lower temperatures and pressures $\left(T_{0} \sim 600 \mathrm{~K}, P_{0} \sim 3 \div 2.8 \mathrm{GPa}\right)$ the thermodynamics allows the transition in a thin layer near pyrope. These results are consistent with results obtained by using a more simple model proposed by Guiraud and Powell [40], which predicts that the higher the initial P-T conditions are the lower the degree of coesite-to-quartz transformation during an exhumation.

In the frame of the proposed multi-shell model, the stress distributions for the composite coesite- $\alpha$-quartz-garnet system comparable with Raman mapping results can be inferred if we assume that originally the system consisted of coesite in the core $(r<10 \mu \mathrm{m})$ surrounded by $\alpha$-quartz shell of radius $20 \mu \mathrm{m}$ sealed in $1-\mathrm{mm}$ garnet crystal at the temperature $T_{0}=1,800 \mathrm{~K}$ and pressure $P_{0}=3 \mathrm{GPa}$ (Fig. 13). The results weakly depend on the ratio of the radii of coesite and quartz. But $T_{0}=1,800 \mathrm{~K}$ is too high for subduction zone and was not documented so far for any UHPM complexes.

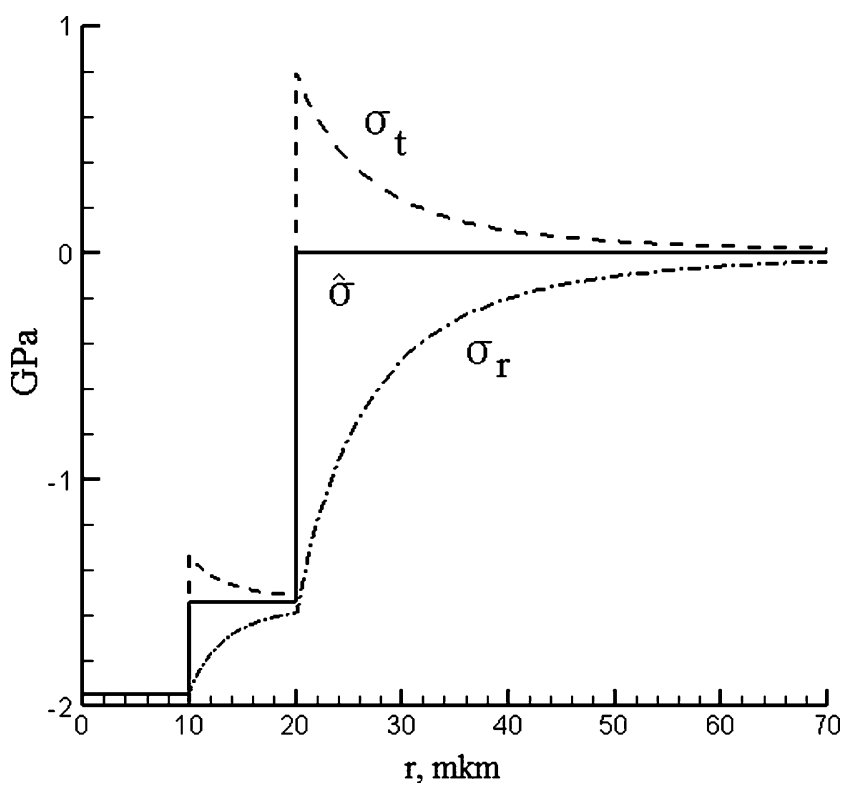

Fig. 13 Calculated $\operatorname{radial}\left(\sigma_{\mathrm{r}}\right)$, tangential $\left(\sigma_{\mathrm{t}}\right)$, and $\widehat{\sigma}=\left(\sigma r+2 \sigma_{t}\right) / 3=$ $-P$ stress distribution in coesite- $\alpha$-quartz-pyrope system for initial conditions: $T_{0}=1,800 \mathrm{~K}, P_{0}=3 \mathrm{GPa}, R_{\mathrm{Coe}, 0}=0.01 \mathrm{~mm}, R_{\mathrm{Qtz}}=0.02 \mathrm{~mm}$, and $R_{\mathrm{Pyr}}=1 \mathrm{~mm}$; and final conditions: $T=298 \mathrm{~K}, P=10^{-4} \mathrm{GPa}, R_{\mathrm{Coe}}=$ $0.01 \mathrm{~mm}, R_{\mathrm{Qtz}}=0.02 \mathrm{~mm}$, and $R_{\mathrm{Pyr}}=1 \mathrm{~mm}$. The elastic properties are taken from [39]

\section{Discussion}

Raman-based geobarometry of deeply subducted crustalderived rocks $[6,8,10,11,16]$, mantle xenoliths or/and diamonds $[5,7]$ reveals that some samples can preserve very high residual pressure inside inclusions. This information is very important because it help us to understand the geological processes, which cause the subduction of crustal-derived protolith to mantle depth $(>150 \mathrm{~km})$, and obtain more reliable estimates of peak metamorphic conditions for such samples.

Raman spectroscopy was recently used to identify minerals in isolated sealed inclusion chambers in some New South Wales (Australia) diamonds and to determine the remnant internal pressure on each inclusion with values of 3.03, 3.31, and 3.54-3.62 GPa for coesite; 0.42, 1.36, and $2.3 \mathrm{GPa}$ for diopsidic omphacite; and $0.8 \mathrm{GPa}$ for grossular garnet [41]. Barron et al. [41] found that the diamond stress due to remnant pressure is proportional to the maximum strain birefringence around each inclusion. They claimed that simple birefringence measurements of diamond adjacent to inclusions can be used to estimate remnant pressures on inclusions. This model later strongly criticized by Howell and Nasdala [42]. Strong birefringent halos were also documented in garnet host around hightemperature coesite [8] and some quartz inclusions [16], but no measurable overpressure was found within these birefringent halos.

The anisotropic stress distribution in the host kimberlitic diamond around graphite inclusions was recently documented by Raman mapping [5, 43]. Kimberlites, the deepest terrestrial magmas and the principal source of diamonds, must have low viscosity and high buoyancy, which govern their exceptionally fast transport from mantle depths to the surface $([44,45]$ and references therein). The very fast uplift of the mantle xenolith by kimberlites (only a few hours) prevents any plastic deformation, despite the fact that $\left|\sigma_{\mathrm{h}}^{\mathrm{tt}}-\sigma_{\mathrm{h}}^{\mathrm{rr}}\right| \gg Y_{\mathrm{h}}$, where $Y_{\mathrm{h}}$ is the yield strength of the host mineral [36]. However the initial pressure can partially release through fracturing of the surrounding host mineral upon heterogeneous expansion of inclusion couples $[46,47]$. The highest values of overpressures (up to $3.6 \mathrm{GPa}$ ) were documented exclusively for various inclusions in kimberlitic diamonds [5, 7, 41, 43].

Exhumation rate of UHPM rocks is much lower (2$5 \mathrm{~cm} /$ year $[48,49])$ compared to very fast uplift of mantle xenolith by kimberlite. However exhumation rates $100 \mathrm{~m} /$ year comparable to ascent rates of magma were recently proposed by Stöckhert et al. [50], based on brittle failure of the garnet host around diamond-bearing $\mathrm{COH}+$ silicate fluid inclusions. Large internal overpressures commonly arise when a rock undergoes decompression without significant cooling [50]. So far the maximum overpressure values for fluid 
inclusion even in diamond were found to be as high as $1.5-$ $2.1 \mathrm{GPa}$ [51], whereas for solid inclusions the overpressure values may exceed $3.5 \mathrm{GPa}[5,7,41,43]$. This fact implies that there are differences in behavior of UHPM fluid and solid inclusions, in particular the solid inclusions having lower-pressure polymorphs (e.g., diamond-to-graphite, coesite-to- $\alpha$-quartz). For instance Raman spectroscopic study of "monocrystalline" coesite inclusions in zircon and garnet reveals that there is discrepancy in pressure estimates for these two $\mathrm{SiO}_{2}$ polymorphs $[6,8,10,11]$. Pressure estimates for coesite (2.0-2.2 GPa) and quartz $(0.8-1.6 \mathrm{GPa})$ were obtained from the pressure dependency of Raman band position by using reported calibration procedures [34, 37]. The difference of $\sim 0.5 \mathrm{GPa}$ indicates that coesite and quartz are not at mechanical equilibrium. But the achievement of mechanical equilibrium is a very fast process [36]. Thus mechanical disequilibrium between coesite and quartz coexisting intimately close is highly unlikely. This discrepancy was one of the main points of criticism of Raman-based geobarometry (M. Ziemann, personal communication, 2002). However there is an alternative explanation for this discrepancy.

Formation of low-pressure polymorphs generally starts at the interface between original high-pressure inclusion and the host mineral. Appearance of a thin shell of lowpressure polymorphs changes the stress distribution drastically in inclusion-host mineral systems. First of all pressure only within the coesite relics is uniform and isotropic, despite the fact that coesite inclusions are not completely spherical and elastically isotropic (see [8], Fig. 2c), while for quartz and garnet shells pressures are non-hydrostatic (Fig. 12). Predominantly pressure dependence of Raman band position was investigated under hydrostatic conditions $[34,37]$. Therefore to get reliable pressure estimates new calibrations of pressure dependence of Raman band position under non-hydrostatic conditions are required.

According to experiments by Harker et al. [52] and Tekippe et al. [53] the sample volume change under uniaxial stress is smaller than that produced in hydrostatic pressure experiments [34, 37]. For instance the first-order Raman shift of diamond shows a strong dependence on hydrostaticity, with very different pressure dependences observed under hydrostatic $\left(\mathrm{d} \nu_{\mathrm{Dia}} / \mathrm{d} P\right.$ is $\left.2.96 \pm 0.05 \mathrm{~cm}^{-1} / \mathrm{GPa}\right)$ and non-hydrostatic $\left(v_{\text {Dia }}=1,332.6+1.294 P-0.0062 P^{2}\right)$ conditions [54]. It is worth noting that under nonhydrostatic conditions the main Raman peak from diamond becomes weak and broad (its FWHM is in the range of 18$121 \mathrm{~cm}^{-1}$, depending on the actual pressure applied) [54]. Unfortunately such information for other geological materials is lacking.

The effect of uniaxial stress on Raman spectra of a single crystal of $\alpha$-quartz was studied by Tekippe et al. [53]. They found that Raman shifts of the most intense quartz bands at
1,081 and $464 \mathrm{~cm}^{-1}$ are about 1.5 and $3.7 \mathrm{~cm}^{-1} / \mathrm{GPa}$. Pressure estimates for quartz shell obtained by using their calibration are $\sim 3.5 \mathrm{GPa}$. This estimate of residual pressure is in good agreement with results of numerical modeling (Fig. 12). This fact indicates that non-hydrostaticity within quartz and garnet shells could be another explanation for deceptive disequilibrium between $\mathrm{SiO}_{2}$ polymorphs.

Although such very high residual pressure $(\sim 3.5 \mathrm{GPa})$ can cause the plastic deformation of quartz and adjacent garnet, experiments [55] reveals that during compression at room temperature, all minerals deform plastically at differential stress of 4-6 GPa. Near isothermal decompression is very common feature of exhumations UHPM rocks [48]. Temperature is generally higher than $700{ }^{\circ} \mathrm{C}$ during this stage $[48,56]$. The higher temperature will promote the fast relaxation of an overpressure inside inclusions $[55,57]$. The maximum upshift of the main Raman band $\left(521 \mathrm{~cm}^{-1}\right.$ under ambient conditions) for coesite inclusion in garnet from different UHPM complexes remains the same, $526 \mathrm{~cm}^{-1}[6,8,11]$, implying that during decompressions an overpressure partly releases due to plastic deformation of garnet host. The plastic deformation also can probably explain the lack of significant overpressure for garnet host adjacent to coesite inclusions, but this question requires an application of TEM and EBSD analyses for such types of inclusion.

Zhang's elastic model [36] predicts that the stress inside the spherical and elastically isotropic inclusion is uniform and isotropic. Raman mapping of aragonite, quartz, and coesite inclusions reveals that in general stress distribution inside semi-spherical inclusions is uniform and isotropic even for elastically anisotropic minerals (Figs. 1 and 8). This fact implies that mineral inclusions with different symmetry provide a very powerful and useful tool for recovery of residual pressure inside inclusions especially from UHPM rocks.

\section{Conclusions}

Despite all the difficulties Raman-based geobarometry is a very useful and powerful tool for recovery of metamorphic conditions. Raman shift of relic phases generally provides the highest values of overpressures. Pressure inside relics of high-pressure polymorphs is hydrostatic and weakly or almost independent from the symmetry of the UHPM relic minerals. Therefore, these relic phases are favorable for recovery of peak metamorphic conditions and numerical modeling of the P-T-t path of the UHPM rocks. Newly formed phase as well as host mineral rarely preserved significant values of overpressure if hydrostatic calibrations of the pressure dependency of Raman band positions were applied. Apparent disequilibrium in pressure estimates for 
two coexisting $\mathrm{SiO}_{2}$ polymorphs within the inclusions can be related to non-hydrostaticity within the quartz shell. Newly formed thin shells of lower-pressure polymorphs are in mechanical equilibrium with high-pressure polymorphs. Pressure release is likely to occur during nearly isothermal decompression, when plastic behavior of the minerals is quite possible. The plastic deformation of the minerals has to be taken into account during geodynamic modeling of subduction and exhumation. Using an adequate thermomechanical modeling we can reconstruct most the probable exhumation P-T path, based on residual pressure, obtained by using pressure dependence of Raman bands of UHPM minerals. However, more systematic Raman spectroscopic studies of different pairs of minerals are required, as well as new calibration of pressure dependency of Raman band positions under non-hydrostatic conditions.

Acknowledgements This study was supported by the Russian Foundation for Basic Research (10-05-00616-a, 10-05-00575-a), Russian Science Support Foundation. Financial support of the Belgian Science Policy-Interuniversity Attraction Poles Program P6/16Belgian State is greatly acknowledged.

\section{Appendix}

Multi-shell elastic model

We assume that a system consisting of $j_{0}$ layers is formed at the pressure $P_{0}$ and temperature $T_{0}$. The first substance occupies a sphere of the radius $r_{1}$, the second occupies the shell $r_{1}<r<r_{2}$, the $j$-th substance occupies the shell $r_{j-1}<r<$ $r_{j}$. We also assume that all processes are slow, so that the temperature will be uniform and the body will maintain in mechanical equilibrium. The temperature of the formation is high and the stress tensor $\sigma_{i k}$ relaxes to an isotropic form: $\sigma_{r r}=\sigma_{\theta \theta}=\sigma_{\varphi \varphi}=-P_{0}$. The radial displacement in initial stage is expressed by the formula

$u_{0}=A_{0 j} r, \quad A_{0 j}=-P_{0} /\left(3 K_{0 j}\right)$

where $K_{0 j}$ is the bulk modulus in $j$-th substance in initial state. Let the system change to an environment with the pressure $P$ and temperature $T$. We assume that during this change the system behaves as an elastic body. Below we indicate the component $\sigma_{r r}$ of stress tensor as $\sigma_{r}$ and $\sigma_{\theta \theta}=$ $\sigma_{\varphi \varphi}$ as $\sigma_{t}$. It is well known [36] that the conditions of equilibrium give the expression for radial displacement $u(r)=C_{1} r+C_{2} / r^{2}$ in each layer. In our case it is more convenient to write for $j$-th substance

$u=\left(A_{j}+B_{j} \frac{r_{j-1}^{3}}{r^{3}}\right) r$
In this notation the total displacement is $u_{\mathrm{tot}}=u+u_{0}$. For the stress tensor we have

$$
\begin{aligned}
& \sigma_{r}=3 K_{j}\left(A_{0 j}+A_{j}-\varepsilon_{j}\right)-4 G_{j} B_{j} \frac{r_{j-1}^{3}}{r^{3}} \\
& \sigma_{t}=3 K_{j}\left(A_{0 j}+A_{j}-\varepsilon_{j}\right)+2 G_{j} B_{j} \frac{r_{j-1}^{3}}{r^{3}}
\end{aligned}
$$

where $\varepsilon_{j}$ is the coefficient of linear expansion due to temperature change and phase transformation, $A, B$, and $C$ are three constants and $G$ is shear modulus. Note, that $\varepsilon_{j}$ can be written as $\varepsilon_{j}=\left(\rho_{0 j} / \rho_{j}\right)^{1 / 3}-1$, where $\rho_{0 j}$ is the substance density at initial temperature $T_{0}$ and zero pressure and $\rho_{j}$ is the substance density at final temperature $T$ and (may be) another phase state also for zero pressure.

The conditions of finiteness of displacement in the center, continuity of radial displacement $u$, and normal stress tensor component $\sigma_{r}$ at the boundary between layers and the condition on the outer boundary of the body may be expressed thus:

$$
\begin{aligned}
& B_{1}=0 \\
& A_{j}+B_{j} w_{j}=A_{j+1}+B_{j+1}, j=1, \ldots, j 0-1 \\
& 3 K_{j}\left(A_{j}+A_{0 j}-\varepsilon_{j}\right)-4 G_{j} B_{j} w_{j}=3 K_{j+1}\left(A_{j+1}+A_{0 j+1}-\varepsilon_{j+1}\right) \\
& \quad-4 G_{j+1} B_{j+1}, \mathrm{~J}=1, \ldots, j 0-1 \\
& 3 K_{j 0}\left(A_{j 0}+A_{0 j 0}-\varepsilon_{j 0}\right)-4 G_{j 0} B_{j 0} w_{j 0}=-P
\end{aligned}
$$

where $w_{j}=r_{j-1}^{3} / r_{j}^{3}$ We solve this system numerically.

\section{References}

1. Chopin C (1984) Coesite and pure pyrope in high-grade blueschists of Western Alps: a first record and some consequences. Contrib Mineralog Petrol 86:107-118

2. Smith DC (1984) Coesite in clinopyroxene in the Caledonides and its implications for geodynamics. Nature 310:641-644

3. Sobolev NV, Shatsky VS (1990) Diamond inclusions in garnets from metamorphic rocks: a new environment for diamond formation. Nature 343:742-746

4. Boyer H, Smith DC, Chopin C, Lasnier B (1985) Raman microprobe (RMP) determinations of natural and synthetic coesite. Phys Chem Miner 12:45-48

5. Nasdala L, Hofmeister W, Harris JW, Glinnemann J (2005) Growth zoning and strain patterns inside diamond crystals as revealed by Raman maps. Am Mineralog 90:745-748

6. Parkinson CD, Katayama I (1999) Present-day ultrahigh-pressure conditions of coesite inclusions in zircon and garnet: evidence from laser Raman microspectroscopy. Geology 27:979-982

7. Sobolev NV, Fursenko BA, Goryainov SV, Shu JF, Hemley RJ, Mao HK, Boyd FR (2000) Fossilized high-pressure from the earths deep interior - the coesite-in-diamond barometer. Proc Natl Acad Sci U S A 97(22):11875-11879

8. Korsakov AV, Hutsebaut D, Theunissen K, Vandenabeele P, Stepanov AS (2007) Raman mapping of coesite inclusions in garnet from the Kokchetav Massif (Northern Kazakhstan). Spectrochim Acta A 68:1046-1052

9. Korsakov AV, Theunissen K, Dobretsov NL (2010) Unusual garnet-coesite/quartz textures and the early exhumation of silica- 
rich UHP crustal rocks of Kulet (Kokchetav, Kazakhstan). J Metamorph Geol (in press)

10. Parkinson CD (2000) Coesite inclusions and prograde compositional zonation of garnet in whiteschist of the HP-UHPM Kokchetav massif, Kazakhstan: a record of progressive UHP metamorphism. Lithos 52:215-233

11. Ye K, Liou JB, Cong B, Maruyama S (2001) Overpressures induced by coesite-quartz transition in zircon. Am Mineralog $86: 1151-1155$

12. Korsakov AV, De Gussem K, Zhukov VP, Perraki M, Vandenabeelee P, Golovin AV (2009) Aragonite-calcite-dolomite relationships in UHPM polycrystalline carbonate inclusions from the Kokchetav Massif, Northern Kazakhstan. Eur J Mineral 21:1301-1311

13. Hutsebaut D, Vandenabeele P, Moens L (2005) Evaluation of an accurate calibration and spectral standardization procedure for Raman spectroscopy. Analyst 130:1204-1214

14. Korsakov AV, Shatsky VS, Sobolev NV, Zayachkovsky AA (2002) Garnet-biotiteclinozoisite gneisses: a new type of diamondiferous metamorphic rocks of the Kokchetav massif. Eur J Mineralog 14:915-929

15. Korsakov AV, Theunissen K, Kozmenko OA, Ovchinnikov YI (2006) Reaction textures in clinozoisite gneisses. Russ Geol Geophys 47:497-510

16. Korsakov AV, Perraki M, Zhukov VP, De Gussem K, Vandenabeelee P, Tomilenko AA (2009) Is quartz a potential indicator of ultrahigh-pressure metamorphism? Laser Raman spectroscopy of quartz inclusions in ultrahigh-pressure garnets. Eur J Mineral 21:1313-1323

17. OBrien PJ, Ziemann MA (2008) Preservation of coesite in exhumed eclogite: insights from Raman mapping. Eur J Mineralog 20:827-834

18. Hermann J (2003) Carbon recycled into deep Earth: evidence from dolomite dissociation in subduction-zone rocks: comment and Reply. Geology 31:e4-e5

19. Korsakov AV, Hermann J (2006) Silicate and carbonate melt inclusions associated with diamonds in deeply subducted carbonate rocks. Earth Planet Sci Lett 241:104-118

20. Dobretsov NL, Sobolev NV, Shatsky VS, Coleman RG, Ernst WG (1995) Geotectonic evolution of diamondiferous paragneisses of the Kokchetav complex, Northern Kazakhstan - the geologic enigma of ultrahigh-pressure crustal rocks within Phanerozoic foldbelt. Isl Arc 4:267-279

21. Shatsky VS, Sobolev NV, Vavilov MA (1995) Diamond-bearing metamorphic rocks of the Kokchetav massif (Northern Kazakhstan). Cambridge University Press, Cambridge, pp 427-455

22. Theunissen K, Dobretsov NL, Korsakov A, Travin A, Shatsky VS, Smirnova L, Boven A (2000) Two contrasting petrotectonic domains in the Kokchetav megamelange (north Kazakhstan): difference in exhumation mechanisms of ultrahigh-pressure crustal rocks, or a result of subsequent deformation? Isl Arc 9:284-303

23. Theunissen K, Dobretsov NL, Shatsky VS, Smirnova L, Korsakov A (2000) The diamond- bearing Kokchetav UHP massif in Northern Kazakhstan: exhumation structure. Terra Nova 12:181-187

24. Korsakov AV, Shatsky VS, Sobolev NV (1998) The first finding of coesite in eclogites of the Kokchetav massif. Dokl Akad Nauk 360:77-81

25. Bischoff WD, Sharma SK, Mackenzie FT (1985) Carbonate ion disorder in synthetic and biogenic magnesian calcites: a Raman spectral study. Am Mineralog 70:581-589

26. Burke E (2001) Raman microspectrometry of fluid inclusions. Lithos 55:139-158

27. Frost RL, Dickfos M (2007) Hydrated double carbonates a Raman and infrared spectroscopic study. Polyhedron 26:45034508

28. Gillet P, Biellmann C, Reynard B, McMillan P (1993) Raman spectroscopic studies of carbonates part I: high-pressure and high- temperature behaviour of calcite, magnesite, dolomite and aragonite. Phys Chem Minerals 20:1-18

29. Liu LG, Mernagh TP (1990) Phase transitions and Raman spectra of calcite at high pressures and room temperature. Am Mineralog 75:801-806

30. Perraki M, Proyer A, Mposkos E, Kaindl R, Hoinkes G (2006) Raman micro-spectroscopy on diamond, graphite and other carbon polymorphs from the ultrahigh-pressure metamorphic Kimi Complex of the Rhodope Metamorphic Province, NE Greece. Earth Planet Sci Lett 241:672-685

31. Scheetz BE, White WB (1977) Vibrational spectra of the alkaline earth double carbonates. Am Mineralog 62:36-50

32. Williams Q, Collerson B, Knittle E (1992) Vibrational spectra of magnesite $\left(\mathrm{MgCO}_{3}\right)$ and calcite-Ill at high pressures. Am Mineralog 77:1158-1165

33. Edwards H, Villar S, Jehlicka J, Munshi T (2005) FTRaman spectroscopic study of calcium-rich and magnesium-rich carbonate minerals. Spectrochimica Acta A 61:2273-2280

34. Hemley RJ (1987) Pressure dependence of Raman spectra of $\mathrm{SiO} 2$ polymorphs: $\alpha$-quartz, coesite, and stishovite. Terrapub, TokyoAGU, Washington, DC, pp 347-359

35. Sharma SK, Mammone JF, Nicol MF (1981) Raman investigation of ring configurations in vitrous silica. Nature 292:140-141

36. Zhang Y (1998) Mechanical and phase equilibria in inclusion-host systems. Earth Planet Sci Lett 157:209-222

37. Schmidt C, Ziemann MA (2000) In-situ Raman spectroscopy of quartz: a pressure sensor for hydrothermal diamond-anvil cell experiments at elevated temperatures. Am Mineralog 85:17251734

38. Zhukov VP, Korsakov AV (2010) Analysis of phase transformation in inclusions and obtaining of residual stress in multi-layered shells: thermomechanical model . Russ Geol Geophys (in press)

39. Holland T, Powell R (1990) An enlarged and updated internally consistent thermodynamic dataset with uncertainties and correlations: the system $\mathrm{K}_{2} \mathrm{O}-\mathrm{Na}_{2} \mathrm{O}-\mathrm{CaO}-\mathrm{MgO}-\mathrm{MnO}-\mathrm{FeO}-\mathrm{Fe}_{2} \mathrm{O}_{3}-\mathrm{Al}_{2} \mathrm{O}_{3}$ $-\mathrm{TiO}_{2}-\mathrm{SiO}_{2}-\mathrm{C}-\mathrm{H}_{2}-\mathrm{O}_{2}$. J Metamorph Geol 8:89-124

40. Guiraud M, Powell R (2006) PVT relationships and mineral equilibria in inclusions in minerals. Earth Planet Sci Lett 244:683-694

41. Barron LM, Mernagh TP, Barron BJ (2008) Using strain birefringence in diamond to estimate the remnant pressure on an inclusion. Aust J Earth Sci 55:159-165

42. Howell D, Nasdala L (2008) Discussion and reply using strain birefringence in diamond to estimate the remnant pressure on an inclusion. Aust J Earth Sci 55:11751180

43. Nasdala L, Brenker FE, Glinnemann J, Hofmeister W, Gasparik T, Harris JW, Stachel T, Reese I (2003) Spectroscopic 2Dtomography: residual pressure and strain around mineral inclusions in diamonds. Eur J Mineralog 15:931-935

44. Kamenetsky VS, Kamenetsky MB, Sharygin VV, Golovin AV (2007) Carbonate-chloride enrichment in fresh kimberlites of the Udachnaya-East pipe, Siberia: a clue to physical properties of kimberlite magmas? Geophys Res Lett 304(9):9316-9321

45. Kamenetsky VS, Kamenetsky MB, Sobolev AV, Golovin AV, Demouchy S, Faure K, Sharygin VV, Kuzmin DV (2008) Olivine in the Udachnaya-East kimberlite (Yakutia, Russia): types, compositions and origins. J Petrol 49(4):823-839

46. Gillet P, Ingrin J, Chopin C (1984) Coesite in subducted continental crust: P-T history deduced from an elastic model. Earth Planet Sci Lett 70:426-436

47. Van der Molen I, van Roermund HL (1986) The pressure path of solid inclusions in minerals the retention of coesite inclusions during uplift. Lithos 19:317-324

48. Hermann J, Rubatto D, Korsakov A, Shatsky VS (2001) Multiple zircon growth during fast exhumation of diamondiferous, deeply subducted continental crust (Kokchetav massif, Kazakhstan). Contrib Mineralog Petrol 141:66-82 
49. Rubatto D, Hermann J (2001) Exhumation as fast as subduction? Geology 29:3-6

50. Stöckhert B, Trepmann CA, Massonne H (2009) Decrepitated UHP fluid inclusions: about diverse phase assemblages and extreme decompression rates (Erzgebirge, Germany). J Metamorph Geol 27:621-633

51. Navon O (1991) Infrared determination of high internal pressures in diamond fluid inclusions. Nature 335:746-748

52. Harker YD, She CY, Edwards DF (1970) Raman spectra of $\alpha$ quartz under uniaxial stress. J Appl Physi 41(13):5274-5278

53. Tekippe VJ, Ramdas AK, Rodriguez S (1973) Piezospectroscopic study of the Raman spectrum of $\alpha$-quartz. Phys Rev B 8:706-716
54. Xu J, Mao H, Hemley RJ (2002) The gem anvil cell: highpressure behaviour of diamond and related materials. J Phys Condens Matter 14:11,549-11,552

55. Yamamoto J, Ando J, Kagi H, Inoue T, Yamada A, Yamazaki D, Irifune $\mathrm{T}$ (2008) In situ strength measurements on natural uppermantle minerals. Phys Chem Miner 35:249-257

56. Hermann J (2003) Experimental evidence for diamond-facies metamorphism in the Dora-Maira Massif. Lithos 70:163-182

57. Yamamoto J, Kagi H (2008) Application of densimetry using micro-Raman spectroscopy for $\mathrm{CO}_{2}$ fluid inclusions: a probe for elastic strengths of mantle minerals. Eur J Mineralog 20:529535 